Chapman University

Chapman University Digital Commons

Economics Faculty Articles and Research

Economics

5-1989

\title{
Financing the Postwar Housing Boom In Phoenix and Los Angeles, 1945-1960
}

Lynne Doti

Chapman University, ldoti@chapman.edu

Larry Schweikart

University of Dayton

Follow this and additional works at: http://digitalcommons.chapman.edu/economics_articles

Part of the Real Estate Commons, and the United States History Commons

\section{Recommended Citation}

Doti, Lynne Pierson, and Larry Schweikart. "Financing the Postwar Housing Boom in Phoenix and Los Angeles, 1945-1960." The Pacific Historical Review (1989): 173-194.

This Article is brought to you for free and open access by the Economics at Chapman University Digital Commons. It has been accepted for inclusion in Economics Faculty Articles and Research by an authorized administrator of Chapman University Digital Commons. For more information, please contactlaughtin@chapman.edu. 


\section{Financing the Postwar Housing Boom In Phoenix and Los Angeles, 1945-1960}

\section{Comments}

This article was originally published in The Pacific Historical Review, in 1989.

\section{Copyright}

University of California Press 


\title{
Financing the Postwar Housing Boom in Phoenix and Los Angeles, 1945-1960
}

\author{
LYNNE PIERSON DOTI AND \\ LARRY SCHWEIKART
}

Lynne Pierson Doti is a member of the

economics department at Chapman College and

Larry Schweikart is a member of the

history department in the University of Dayton.

Real-estate booms have occurred regularly in the American past and played an important role in the settlement of both rural and urban areas. ${ }^{1}$ After World War II, Americans experienced a general migration from rural to urban and suburban areas and from the Midwest and East to the so-called "Sunbelt states," particularly Florida, Texas, Arizona, and California. California and Arizona both grew by more than a hundred percent between 1945 and 1960, and

Larry Schweikart wishes to acknowledge financial support received from the Research Institute of the University of Dayton, the Charles Redd Center for Western Studies, and the Earhart Foundation.

1. Material on land booms appears in Vernon Carstensen, ed., The Public Lands (Madison, 1963); Douglass North, The Economic Growth of the United States, 1790-1860 (Englewood Cliffs, N.J., 1961); North, Growth and Welfare in the American Past (Englewood Cliffs, N.J., 1966); Paul Wallace Gates, "The Role of the Land Speculator in Western Development," Pennsylvania Magazine of History and Biography, LXVI (1942), 314-333; Allan and Margaret Bogue, "Profits and the Frontier Land Speculator," Journal of Economic History, XVII (1957), 1-24;

Pacific Historical Review @ 1989 by the Pacific Coast Branch American Historical Association 
two cities that reflected this phenomenal increase were Phoenix and Los Angeles. Both shared more than sunshine. During the war they had supported numerous defense workers and thousands of military personnel, many of whom passed through the two cities on their way to the front. The G.I. bill, with its offer of inexpensive financing and low down payments for housing, persuaded newcomers to stay, and earlier visitors to return and buy homes-homes that could be built and sold inexpensively because Phoenix and Los Angeles possessed large parcels of agricultural land suitable for conversion to mass-produced tracts of housing. Both cities had automobile-based transportation systems in place by World War II, and developers no longer had to depend upon public transit facilities to entice buyers. Although scholars have described the urban growth of Phoenix and Los Angeles during the fifteen years following World War II, they have largely ignored the financial arrangements that supported the residential boom in the two cities. ${ }^{2}$ A review of the real estate market from 1945 to 1960 reveals that banks and other finan-

Milton Heath, Constructive Liberalism (Cambridge, Mass., 1954); John Kenneth Galbraith, The Great Crash (Boston, 1955); and Richard Sylla, "Federal Policy, Banking, Market Structure and Capital Mobilization in the United States, 1863-1913," Journal of Economic History, XIX (1969), 659-686; Gene Smiley, "Interest Rate Movements in the United States, 1888-1913," ibid., XXV (1975), 591-620; and John James, "The Development of the National Money Market, 1893-1911," ibid., XXXVI (1976), 878-897. Land booms in the nineteenth century, as well as speculative activity in Florida in the twentieth century, were shaped by the availability of credit. In these early booms, credit was supplied mostly by the federal government, railroad companies, or individuals who made financing available as an adjunct to the sale of property they had acquired in anticipation of the boom. Organized financial institutions generally developed after the speculative fever had cooled.

2. For background on the growth of Phoenix and Los Angeles, see Bradford Luckingham, "The City in the Westward Movement: A Bibliographical Note," Western Historical Quarterly, V (1974), 305; Luckingham, The Urban Southwest: A Profile History of Albuquerque, El Paso, Phoenix, and Tucson (El Paso, Tex., 1982); Geoffrey P. Mawn, "Phoenix, Arizona: Central City of the Southwest, 1820-1920" (Ph.D. dissertation, Arizona State University, 1979); Michael Kotlanger, Jr., "Phoenix, Arizona: 1920-1940" (Ph.D. dissertation, Arizona State University, 1983); Johnathan Kandell, "Historians of West Are Shedding 'Cowboy' Image and Gaining Acceptance," New York Times, Oct. 15, 1972; D. W. Meinig, Southwest: Three Peoples in Geographic Change, 1600-1970 (New York, 1971); W. Eugene Hollon, The Southwest: Old and New (Lincoln, Neb., 1961); Kirkpatrick Sale, Power Shift: The Rise of the Southern Rim and Its Challenge to the Eastern Establishment (New York, 1975); Carl Abbott, "The American Sunbelt: Idea and Region," Journal of the West, XXVIII (1979), 7, 8; and Abbott, The New Urban America: Growth and Politics in Sunbelt Cities (Chapel Hill, 1982). 
cial institutions were in the forefront of the rapid real-estate expansion and that this expansion had a profound effect on these institutions. ${ }^{3}$

Real estate financing following the war came primarily from three types of financial institutions-commercial banks, savings and loan companies, and insurance companies - with the first two playing by far the most important role. Savings and loan associations - mutual savings associations in which members (depositors) owned all the shares-specialized in holding interest-paying time deposits and making real estate loans. Commercial banks were publicly held corporations that specialized in demand deposits (checking accounts on which interest payments were not allowed from 1934 to 1980) and consumer and business (commercial) loans. Commercial banks chartered by the federal government were restricted in their ability to lend on real estate, but California and Arizona did not place similar restrictions on their state-chartered banks. At various times, commercial banks with state charters were active lenders in these markets. Insurance companies used accumulated premiums to purchase loans from the primary lenders and also made construction loans directly to developers. Although in Los Angeles savings and loan associations (S\&Ls) played a major role in financing residential growth, in Phoenix new banks created the initial development spark, and S\&Ls and other nonbank financial institutions lured buyers with easy credit. Insurance money, mostly from firms headquartered in the East, was important in both Arizona and California. ${ }^{4}$

3. Bradford Luckingham, "Phoenix: The Desert Metropolis," in Richard Bernard and Bradley Rice, eds., Sun Belt Cities: Politics and Growth Since World War II (Austin, 1983), 309-327; Remi Nadeu, Los Angeles: From Mission to Modern City (New York, 1960), 59, 73. On Huntington, see William Friedricks, "Henry Huntington and Metropolitan Entrepreneurship in Southern California, 18981917" (Ph.D. dissertation, University of Southern California, 1986).

4. Secondary sources on banking in Arizona and California are found in Larry Schweikart and Lynne Pierson Doti, "Banking in the West: A Bibliographical Introduction," in Schweikart, ed., Banking in the West (Manhattan, Kan., 1984), 88-94. During the early development of American banks, as well as those in Europe, real-estate lending posed too great a risk for financial institutions. Savings and loan associations, originally called building and loan societies, started as cooperative arrangements of savers who pooled their funds to build the members' homes. These societies were often converted to financial institutions, and by 1940 savings and loan associations specialized in real-estate lending and savings deposits. 
In Phoenix, commercial bankers promoted and fueled the real estate market. Moreover, they engaged in boosterism and encouraged outsiders to move to the area as much as real estate brokers and developers did. The firms that captured the new mortgage business were small, new entrepreneurial banks that operated in competition with the established banking "oligopoly." The success of these banks revealed the openness of financial markets. Although they still had to obtain a charter, there were few barriers to entry, especially since the larger banks had failed to recognize the potential of the real estate and mortgage markets. A similar shift in financial power occurred in the Los Angeles area. Commercial banks, once active lenders in the real estate market, lost a large share of this business to the more aggressive promotion efforts of the burgeoning savings and loan industry.

Arizona's population growth began in earnest following World War II, picking up momentum in the 1950s with the widespread use of air conditioners. Virtually all of the population and business growth from 1946 to 1960 occurred in Phoenix and Tucson, with the former spurting past its southern neighbor to become one of the largest cities in the Southwest. Phoenix's population quadrupled to over 439,000 , its manufacturing output soared by almost 1,500 percent, and its incorporated area grew elevenfold. The city's economic growth, together with the natural beauty and healthful climate, pulled in still others-mostly professionals, engineers, and technicians. ${ }^{5}$

Among the biggest attractions was affordable real estate. Young Arizona developers such as John F. Long, Del Webb, Ralph Staggs, John Hall (Hallcraft Homes), Sam and Jack Hoffman (F \& S Construction), and David Murdock tapped

5. Michael Konig, "Postwar Phoenix, Arizona: Banking and Boosterism," Journal of the West, XXIII (1984), 72-76. See also Schweikart, "Collusion or Competition? Another Look at Banking in Arizona's Boom Years," Journal of Arizona History, XXVIII (1987), 189-200; Schweikart, A History of Banking in Arizona (Tucson, 1982), 115-147; Michael Konig, "Toward Metropolis Status: Charter Government and the Rise of Phoenix, Arizona, 1945-1960" (Ph.D. dissertation, Arizona State University, 1983).

The term "Phoenix" refers to the "Valley of the Sun," Phoenix and its metropolitan area. Because of rapid expansion and annexation the term varied even in official definitions, but in 1960 would include most suburbs. 
into the growing construction market in the early 1950 s. While Long, Hall, Staggs, and the Hoffman brothers concentrated on residential housing, Webb and Murdock worked on skyscrapers, hotels, and office buildings. Realtors such as Russ Lyon actively participated in "selling" the state in the early 1960s. After the war the only restriction on Arizona's growth was cool air and ready cash. Air conditioners solved the first problem, but Arizona's depression-toughened banks could not supply enough credit to turn the tremendous potential of Phoenix into a marketable community. It was the federal government that provided the resources to generate this credit. 6

Much of Washington's interest in the state began during the war. Given the number of new and expanded military bases, housing was in short supply while the conflict raged, and the federal government classified the state as a "critical housing area," permitting Arizona developers to build when other areas of the country were denied the privilege. This availability of housing led promoters in the 1950s to note that, when industrial recruiters "advertised for skilled laborers in two locations simultaneously, the ratio of those who preferred Arizona to another location was between 5 to 1 and 8 to $1 . " 7$

Valley National Bank, headquartered in Phoenix and under the leadership of Walter and Carl Bimson, brought government credit into the state via another route, Federal Housing Administration loans, which dated back to 1934 and the passage of the National Housing Act. Carl, who was instrumental in lobbying for the legislation, in 1935 took over the promotion of housing and real estate in Arizona. He "made a crusade of it, organizing crews to ring doorbells and talk up loans." In 1958 alone, construction permits in Tucson rose

6. Harold Martin, "The New Millionaires of Phoenix," Saturday Evening Post, Sept. 30, 1961, pp. 25-30 (quotation from p. 30); Schweikart, That Quality Image: The History of Continental Bank (Tappan, N.Y., 1988). Other material on Continental Bank appears in the Archives of Continental Bank (hereafter cited as CB Archives), Chase Bank of Arizona, Scottsdale, Ariz.

7. Larry Schweikart, interview with Carl Bimson, March 25, 1980, p. 1, in taped interview collection, Arizona State University Library (hereafter cited as ASUL), Phoenix. 
324 percent. That same year Phoenix issued more than ten thousand building permits. Valley Bank made $\$ 400,000$ worth of FHA-related mortgages in a single year, and over the same period the bank also invested $\$ 600,000$ in uninsured loans in the Phoenix market. The state as a whole exceeded its FHA quota of $\$ 3$ million in loans. From 1934 to 1945, Valley Bank alone made over 198,000 loans and had reached a national ranking of fifth in originating FHA loans in $1935 .^{8}$ By 1945 , Valley Bank held so many FHA loans that it could not make any more and still maintain a permissible loan-to-reserves ratio; thus, it attempted to broker the loans to third parties. When Transamerica, a large financial holding company that operated in five states at that time, purchased $\$ 1$ million of the loans, Valley Bank advertised that it had an additional $\$ 1$ million to lend locally. The real boom, however, still lay ahead. 9

In 1947 a small Phoenix insurance agency, the A. B. Robbs Agencies, received a phone call from Jack R. Smith, the West Coast investment representative of National Life of Vermont. Smith was seeking an Arizona correspondent to originate FHA and Veterans Administration loans, which were federally insured loans to assist veterans in obtaining home loans. Although A. B. Robbs, Sr., wanted nothing to do with any government agency for ideological reasons, his son, A. B., Jr., immediately recognized the potential for a program of this type. One hurdle had to be cleared. To originate FHA loans, the Robbs company had to have a net worth of $\$ 100,000$, but it was capitalized at only half that amount. National Life solved the problem by appointing the Arizona firm its mortgage loan correspondent, thus guaranteeing the minimum net worth. Between 1947 and 1950 the Robbs company acquired

8. Ibid:; Schweikart interview with Bimson, April 7, 1980, ibid; Bimson speech, Oct. 1952, in "Speeches of Carl Bimson," 127-136, unpublished collection at Valley National Bank, Phoenix; "Condensed Financial Statement" of National Bank for year ending 1939, ibid. Residential housing starts for the greater Phoenix area in 1954 and 1959 were, respectively, 8,910 and 17,903. For the same dates in the Los Angeles area, the housing starts were 104,082 and 90,269. U.S. Bureau of the Census, Housing Construction Statistics, 1889-1964 (Washington, D.C., 1966), 108, 123.

9. Schweikart, Bimson interview, March 25, 1980, pp. 4-5, ASUL; Ernest Hopkins, Financing the Frontier (Phoenix, 1950), 248. 
the accounts of eight other eastern investors, who purchased more than $\$ 12$ million in FHA/VA mortgages. In addition to initiating the loans, the Robbs agency collected the mortgages from local households for a service fee. In the case of refinancing, the firm dealt with the tedious and confusing problems of sorting out the paperwork. Because each eastern investor was involved with thousands of contracts in a distant state, the Robbs Agencies filled an important and profitable niche by providing these mortgage-servicing functions. ${ }^{10}$ The volume of business conducted by this single firm was large not only for Arizona, but also in comparison to other Sunbelt states. In 1947, the Robbs firm alone did a third as much residential real-estate business as all the banks in Oklahoma combined.

Gradually, the Robbs Agencies expanded into mortgage banking, and had the added business of insuring each new house that it financed. By 1950 the company had reached a level of $\$ 100,000$ net worth and obtained a charter as an FHAapproved mortgagee in its own right, thereby enabling the firm to sell the mortgages it originated to numerous companies approved by the FHA. It then expanded into the Tucson market as an independent but affiliated company-Newell \& Robbs, Mortgage Bankers.

In 1958, the A. B. Robbs Agencies became A. B. Robbs Trust Company, with powers similar to a commercial bank, including the privilege of accepting deposits and making all varieties of loans. Its growing FHA-mortgage-generating capacity coincided with the appointment of a mortgage lending officer at Valley Bank whose "abrasive and opinionated" attitude had driven many of the young builder-developers away from that bank and into the offices of the A. B. Robbs Trust Company. ${ }^{11}$

Even more important to the growth of Robbs's mortgage-

10. Schweikart, interview with A. B. Robbs, Jr., June 27, 1985, CB Archives; A. B. Robbs Company minute books, box 6, A. B. Robbs, Jr., Papers, ibid.

11. Schweikart interview with Ruby Nelson, tape in CB Archives, June 24, 1984; Schweikart, That Quality Image, 6. A trust company invested in various assets, including mortgages, on behalf of its customers. Trust companies also packaged mortgages and provided investors with bonds or with shares of the trust itself. 
lending capacity than the developers' disaffection with Valley Bank and the disinterest of the other major banks was the firm's access to great amounts of mortgage capital in the hands of eastern investors. Robbs, Jr., personally sought out these investors, making tedious twenty-hour flights to New York in uncomfortable DC-9s. Relying purely on footwork and salesmanship, Robbs located likely prospects in the phone book, made appointments with them, and sold them on Arizona. $\mathrm{He}$ arrived at exclusive agreements with John Hancock Mutual Life Insurance Company, Travelers, Paul Revere Life Insurance Company, and a host of East Coast and Midwest savings banks. Among these savings institutions, the Williamsburgh Savings Bank, Seamen's Savings Bank, People's Savings Bank, and Bowery Savings Bank formed a New York base that served Continental Bank (which the Robbs Trust Company became in 1964) to the present. These secondary market sources had, by 1953 , purchased $\$ 30$ million worth of Arizona mortgages (Table 1). The Southwest represented a fertile investment field for home mortgages that became increasingly difficult to obtain in the East, both because of higher property costs and because of the growing attraction of Sunbelt cities. ${ }^{12}$

As eastern capital funnelled into Arizona, the housing boom reached its postwar peak. Phoenix ranked eleventh in the nation in 1958 with 16,200 new dwelling units, almost double the number constructed in 1956. As seen in Table 2, virtually all of the Phoenix construction consisted of singleunit homes, not apartments, indicating that the mortgage money contributed heavily to the housing boom. Of the new construction in Maricopa County, of which Phoenix is the hub, the A. B. Robbs Trust Company commanded twenty percent of the total mortgage-loan market for new housing. Robbs-related companies recorded mortgages totaling more than $\$ 2.5$ million in May 1959 alone. ${ }^{13}$

Many of the Robbs Trust Company's nonresidential con-

12. Schweikart, That Quality Image, 8-10. Continental merged with Chase in 1985, and is now Chase Bank.

13. See A. B. Robbs Trust Company, "Dispatch," June 1959, CB Archives. Pima County, in which Tucson is located, also grew, but at less spectacular rates; building permits rose from 3,303 in 1956 to 4,206 in 1958 . 
Table 1. A. B. Robbs Company: Outstanding Principal Balances as of the December, 1953, Closings

\begin{aligned} & \hline$\$ 2,798,776.64$ National Life of Vermont \\ & $5,759,310.13$ John Hancock Mutual Life \\ & $305,832.82$ Kansas City Life \\ & $572,193.78$ Paul Revere Life \\ & $3,225,275.86$ Brooklyn Savings Bank \\ & $653,591.61$ City Savings Bank \\ & $101,041.26$ Columbia National Life \\ & $737,255.36$ Dollar Savings Bank \\ & $1,385,954.90$ Eastchester Savings Bank \\ & $1,156,181.71$ East River Savings Bank \\ & $2,792,402.70$ Erie County Savings Bank \\ & $3,816,310.99$ Federal National Mortgage Association \\ & $210,039.94$ Greater New York Savings Bank \\ & $2,969,948.12$ Greenwich Savings Bank \\ & $789,875.94$ American Irving Savings Bank \\ & $292,288.01$ Massachusetts Protective Association \\ & $584,053.61$ New Hampshire Savings Bank \\ & $1,258,573.54$ People's Savings Bank \\ & $716,564.64$ Philadelphia Savings \& Loan Society \\ & $70,949.74$ Half-Dime Savings Bank \\ & \hline$\$ 30,196,421.30$ 20 investors \\ & \hline\end{aligned}

Source: A. B. Robbs Company ledger

Table 2. Type of Housing Structures, 1954-1960 (in thousands of units)

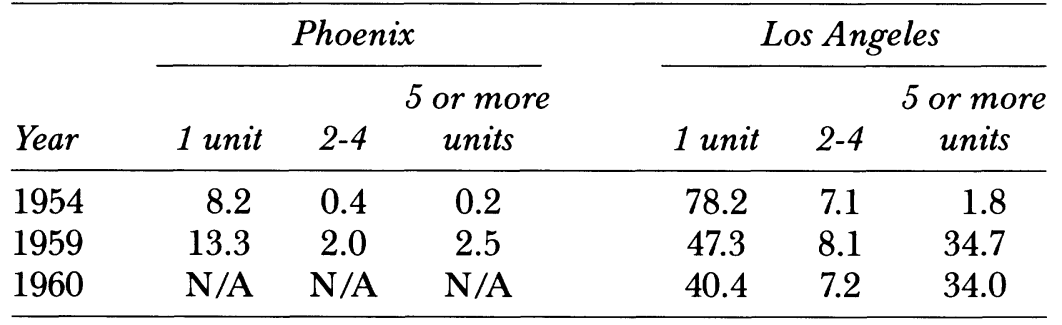

Source: U.S. Bureau of the Census, Housing Construction Statistics, 1899-1964 (Washington, D.C., 1966), 108, 123. 
struction loans went to developer David Murdock. After receiving a loan from Valley Bank that pulled him out of early financial troubles, Murdock again returned to Robbs for funds for "multimillion-dollar redevelopment of whole downtown blocks." By 1961 he had constructed nineteen office buildings in Phoenix, including the city's first skyscraper of significance (the Guaranty Bank Building), and in the process had borrowed $\$ 20$ million, mostly through Robbs Trust Company financing. ${ }^{14}$

While the A. B. Robbs Trust Company was the most active firm in both Phoenix and Arizona mortgage lending, it was by no means the only one. Jim Patrick, executive vicepresident of the Valley Bank, sought to mend the rift between Valley and the developers that had existed since the early 1950s. To repair the damage, he often "served as guide, counselor and financial backer" to most of the developers, lending to many of the same builders as Robbs. But Patrick's bankunlike the Robbs Trust Company-did not have access to eastern capital. In 1963, for example, the Robbs Company had forty-nine eastern investors whose principal balances in the Robbs Trust Company totaled $\$ 228.6$ million that was used by the Arizona company to make FHA loans on real estate. No other bank in the state could boast such capitalization. ${ }^{15}$

Due to the potential gains in areas of development and finance, yet to be tapped by either the A. B. Robbs Trust Company or existing banks, Robbs had, during the early 1960s, joined developer David Murdock in an alliance to create yet another financial entity specifically designed to handle all aspects of the real estate business, Financial Corporation of Arizona (FCA). FCA consisted of several firms merged into one broad financial services institution that Robbs called "the first publicly held, diversified financial holding company in Arizona." It had the potential of expanding even further until a vice-president embezzled more than $\$ 1$ million, causing FCA to collapse. ${ }^{16}$

15. Ibid.; Continental Bank, "Total Servicing," CB Archives.

16. Schweikart, That Quality Image, 13-14; Schweikart interviews with Robbs 
Still seeing other investment opportunities, but dissatisfied with FCA, in 1964 Robbs opened his own bank, Continental National Bank. In addition to retaining all of the original Robbs Trust Company accounts, Continental cultivated new relationships with builders and investors. George Steinhilber took over the mortgage lending operations in 1964 and assumed the difficult but critical task of cultivating the eastern accounts and, in the process, assuming Robbs's mantle of booster, promoting Phoenix as well as the trust company. The Robbs Company's conversion to a bank was in many ways a forerunner of modern deregulation, wherein banks are permitted to enter mortgage lending to a greater extent. ${ }^{17}$

While Robbs was the most important of the Arizona financiers and boosters, there were others. The Phoenix Chamber of Commerce recognized the value of an official city "promoter" and named Patrick Downey, an executive for Valley Bank, to that post. He lobbied such companies as Motorola, General Electric, and Sperry-Rand, always presenting target firms with a dossier on Phoenix - which included maps, tax information, labor statistics, and weather reports-that sold the city and the state as "especially conducive to technical industrial growth.” These professionals - technicians and white-collar workers-purchased much of the new residential housing in the 1950s after Downey, the chamber, and Valley Bank had "advertised" to their employees the virtues of the Sunbelt. At first the chamber of commerce purchased Downey's services from the bank, but when its funds became inadequate, Valley Bank paid Downey's salary for his promotional work. First National Bank also paid for individuals to work on behalf of the chamber of commerce, thus subsidizing boosterism for the city and state. Through bank-sponsored

and Lilymae Penton, July 19, 1985, CB Archives; Archie Kleven to Robbs, Jr., Aug. 12, 1963, folder 24, box 2, A. B. Robbs, Jr., Papers. Other material was provided in an off-the-record discussion that Schweikart had with David Murdock, May 29, 1986. Robbs lost half a million dollars; Murdock barely avoided bankruptcy, but doggedly rebuilt his company until it eventually stood as a national powerhouse among development firms.

17. Robbs interview; Schweikart, That Quality Image, 14-23; A. B. Robbs, Jr., Papers, C. B. Archives; "Application to Organize a National Bank," folder 1, box 13, ibid.; Schweikart interview with George Steinhilber, July 2, 1985. 
publications such as Arizona Progress and Arizona, the state's banks encouraged residential real-estate sales by relating statistics on public schools, taxation, labor, and employment growth. ${ }^{18}$

Thus, at the same time that great amounts of eastern capital began to flood into Arizona, enticed by the success of Valley Bank and the chamber's campaign and then facilitated by the A. B. Robbs Trust Company, important elements of the Phoenix banking community as a whole stimuated demand, especially in Phoenix. And because the interest rates provided by the FHA/VA mortgages were favorable, consumers had further reason to increase their demand for loans.

Once the large corporations had moved into the Phoenix area and begun profitable operations, many of their engineers and mid-level executives broke off to form their own companies. Encouraging them to do so and sustaining the real-estate boom was the availability of start-up capital for small businesses. Such financing had earlier been largely ignored by local financial institutions. In 1963 the void was filled by a small, highly specialized firm, Thunderbird Bank. Sensing the change in local business patterns, its president, Robert McGee, shifted the bank's lending patterns to emphasize business credit instead of commercial or agricultural loans. During the late 1960s Thunderbird Bank emerged as a leading small-business bank in the Southwest and encouraged other lending institutions to follow its lead. By supplying credit to local entrepreneurs, Arizona's banks also ensured that longterm growth would succeed the short-term boom. ${ }^{19}$

Arizona savings and loan companies also participated in the Phoenix land boom, with first-mortgage loans growing from $\$ 2.9$ million to $\$ 92$ million between 1946 and 1960 . Over the same period, the number of savings and loans firms grew from two to seven, and one company clearly led the way. Western Savings and Loan made more than half (\$54.5 mil-

18. Transcript of an interview with Patrick Downey, July 8, 1978, Phoenix History Project, Western Savings Building, Phoenix; Konig, "Postwar Phoenix," 73.

19. On Thunderbird Bank, see Schweikart, A Dynamic Legacy: Thunderbird Bank, 1964-1985 (Phoenix, 1986). 
lion) of the first mortgage loans extended by all S\&Ls in $1960 . .^{20}$ Still, this involvement by S\&Ls remained a small segment of the mortgage market; in 1953 the Robbs Company alone loaned $\$ 30$ million-some $\$ 7$ million more than the existing five savings and loan companies combined. It is also important to note that little "backflow"-the lending of California mortgage money to Arizona institutions-occurred. Had the California S\&Ls been anxious to lend, they would have found local demand more than sufficient for the investment of their funds. The records of the Arizona banks indicate that the sources of all outside mortgage funds were in the eastern states. Likewise, the books show that none of Arizona's mortgage money was used to buy California mortgages ("relending"). In both Phoenix and Los Angeles the demand for financing soaked up all available local funds.

In contrast to the situation in Arizona, California commercial banks, and particularly the smaller banks, were generally reluctant to extend credit to the real-estate market. Although the amount that all commercial banks loaned on mortgages as a percent of assets rose from 6.9 percent in 1945 to 20.7 percent in 1956, only a few of the largest banks participated. The reluctance of commercial bankers to meet the needs of developers and homeowners resulted in a very rapid growth in the number and size of savings and loan associations in California and stimulated inflows of large amounts of mortgage money through national life insurance companies. ${ }^{21}$

California's postwar growth was also accelerated by the military concentrations and the defense and service industries that arrived during the war. The population soared from 6.9 million in 1940 to 10.6 million in 1950. Los Angeles

20. Arizona Banking Dept., Annual Reports (Phoenix, 1946-1960).

21. Richard Towey and Robert Lindsay, "Liquidity of California Banks," in Hyman Minsky, ed., California Banking in a Growing Economy, 1946-1975 (Berkeley, 1964), 143. It should be noted that, unlike in Arizona, many corporate and bank archives in California are closed or restricted, and reports such as those cited in Minsky's volume contain much of this restricted material. Primary sources, in these cases, were not available to the authors. For other general material on California, see Governor's Banking and Study Committee, On the Future of Banking in California (San Francisco, 1965). 
remained one of the fastest growing areas in the nation in the 1950 s, the number of residents expanding by over fifty-four percent in the decade. This phenomenal increase exceeded the willingness of the commercial banks in the metropolitan area to provide adequate financing. Although there was tremendous expansion in real-estate lending, most banks tended to invest in the bond market, replacing war bonds in their portfolios with school, utility, and other public issues. The exceptions were three or four of the state's largest commercial banks, including the Bank of America. ${ }^{22}$

Though few in number, they loaned staggering amounts of money, especially in Los Angeles, where their share of the mortgage market exceeded that of all other local agencies combined. As early as 1948 the Bank of America had $\$ 600$ million in Veterans Administration loans, or about ten percent of all such loans in the nation. ${ }^{23}$ The Bank of America's foray into real-estate lending during the war and postwar period was a departure from the policy of founder A. P. Giannini, who in contrast to A. B. Robbs, Jr., and Gilbert Bradley in Arizona, had opposed loans to real-estate developers. The new strategy may have reflected a turnover in management but was probably due more to the patriotic aura that new housing had gained in the war years. The bank granted Los Angeles builder Paul Trousdale advances of up to eight million dollars when he was building "two houses a day, seven days a week," for war-industry employees; this sum multiplied fourfold within a few years after the war. When Henry Kaiser applied his Liberty ship methods to postwar home building in southern California, the Bank of America extended some $\$ 50$ million for a single project call-

22. John Cox, "Institutional Mortgage Lending in the Los Angeles Metropolitan Area, 1953-54 and 1957-58" (Ph.D. dissertation, University of Southern California, 1962), 44. In the 1950 census, the Los Angeles/Long Beach Standard Metropolitan Statistical Area (SMSA) included Orange County. Orange County began to grow rapidly in the 1950s and was a separate Standard Metropolitan Statistical Area (Anaheim/Santa Ana/Garden Grove) in the 1960 census. Growth in the SMSA was 225 percent between 1950 and 1960. The term "Los Angeles area" refers to the pre-1960 definition.

23. Marquis James and Bessie James, Biography of a Bank: The Story of Bank of America (New York, 1954), 417, 490; Federal Reserve Board of Governors, Federal Reserve Board: All Bank Statistics, 1896-1969 (Washington, D.C., 1965). 
ing for six thousand homes. Meanwhile, Henry Doegler received \$75 million from the bank for developments west of Los Angeles. But most commercial banks avoided developers, apparently sharing the pride of the Farmers and Merchants Bank of Los Angeles which boasted that it "rarely made loans to subdividers and builders for the development of large tracts." ${ }^{4}$

There had been a brief flirtation with the mortgage markets by commercial banks in the years 1946-1950, when banks were holding over half of the institutionally held mortgage debt in the state. Banks were particularly attracted to the federally guaranteed mortgages, viewing them as a safe and liquid investment. The large amount of savings deposits provided a stable source of funds for this lending. ${ }^{25}$ But even in the early postwar period, when a few banks dominated the primary mortgage market, this large amount of deposits meant California banks as a group never approached the legal limits for real-estate loans in their portfolios. Federal statutes allowed a chartered national bank to loan on real estate up to sixty percent of its time deposits, and government-insured loans were excluded in making this calculation. State banksthose chartered under California law - had no limit on the total amount of their investments that they could devote to real-estate loans. The generous ceilings, and very high volume of time deposits, which constituted nearly half of all California bank deposits in the early postwar period, ensured that few banks were constrained by regulatory restrictions. Los Angeles banks, for example, could have doubled their total real-estate loans outstanding for 1946-1951 and still not have exceeded federal limits. 26

After 1950, banks declined rapidly in importance relative

24. James and James, Biography of a Bank, 241, 470, 490; Robert Cleland and Frank Putnam, Isaias Hellman and the Farmers and Merchants Bank (San Marino, Calif., 1965), 102.

25. Frederic Morrissey, "The Allocation of Funds by the Commercial Banks in the California Economy, 1946-1975," in Minsky, ed., California Banking, 249; James Gilles and Clayton Curtis, Institutional Residential Mortgage Lending in Los Angeles County, 1946-51: Six Significant Years of Mortgage Lending (Los Angeles, 1956), 66.

26. Federal Reserve Board, All Bank Statistics, 150; Gillies and Curtis, Institutional Residential Mortgage Lending, 70. 
to other real-estate lenders. It is not clear why banks failed to respond to the demand for real-estate loans, but two factors probably contributed. The first was the leveling off of prices in the real-estate market that began in 1949. This three-year lull may have reminded the banks of earlier real-estate booms in the 1800s, 1920s, and other less spectacular years when suddenly overextended borrowers had caused bankers to lose sleep. Another possible reason for the shift could have been the attraction of rising interest rates on government bonds. In 1946 and 1947, banks had been anxious to move out of low-yielding government bonds, but by 1948 the differential between mortgage rates and interest rates on federal, state, and local bonds had declined. A temporary disturbance in the secondary market for government-insured mortgages, caused by the dissolution of the Reconstruction Finance Corporation (RFC), may also have contributed to the bankers' loss of enthusiasm for mortgages. From October 1946 to the middle of 1947, lenders could sell VA-guaranteed loans to the RFC Mortgage Company. The RFC was discontinued in July 1947; the newly created agency, Federal National Mortgage Association, was not allowed to buy VA mortgages in large quantities from a single lender until October 1949. That disturbance in the secondary market caused a distinct corresponding drop in new VA mortgages.

As increases in the number of real-estate loans in bankers' portfolios moderated, the gap was quickly filled by savings and loan associations and life insurance companies. The growth of the savings and loan associations was rapid and surprising, as recorded in the Annals of the United States savings and loan industry from 1946 to 1954. Among the articles expressing fear of communism and public housing, there were steadily increasing comments on events in California. In 1949, the Annals noted that California savings and loan associations held about $\$ 870$ million in mortgage loans, making its savings and loan industry the third largest in the nation, behind the traditionally strong savings and loan associations of Ohio and New York. The entire industry had about $\$ 10$ billion in loans outstanding nationwide that year. In 1952 the association reported that California S\&Ls had 
moved into second place in the size of assets. A year later California's growth rate was the fastest among the states33 percent compared to 18 percent nationwide. In 1954 leaders of the organization registered congratulations and astonishment when California savings and loan associations increased their assets by another $\$ 512$ million and reported $\$ 2.3$ billion in outstanding mortgages. ${ }^{27}$

The growth of the savings and loan industry in California continued throughout the 1950s. A 1960 report by the Stanford Research Institute calculated the growth in new firms over the decade at 34 percent, the number of home and branch offices at 159 percent, and the growth rate in the number of mortgage loans at 521 percent. Most of this increase occurred in southern California; 65 percent of the assets of the savings and loan associations in California in 1959 were in the portfolios of firms headquartered in Los Angeles. ${ }^{28}$ This aggressive expansion by the savings and loan industry did not, however, make the mortgage market independent of the commercial banks where much larger overall size continued to make them the largest holders of mortgages.

Still, the rising importance of savings and loan associations did have a significant impact on the mortgage market. S\&Ls were more willing than banks to lend in the "used" housing market with about half their loans financing resales rather than new construction. Builders and developers, especially in southern California, found savings and loans more accommodating than banks. They provided more funds for a project and were more generous in their estimates of the borrower's credit-worthiness. Although there were large variations between individual savings and loan associations, an overall shift occurred in their preference for more profitable conventional loans rather than FHA or VA loans. ${ }^{29}$ In the 1950s and 1960s the S\&Ls built a base of conventional loans using government-insured loans primarily as a liquid asset since they could be easily converted to cash. This liquidity

27. United States Savings and Loan League, Savings and Loan Annals (1946-1954); Annual Reports of the United States Savings and Loan League (1946-1954).

28. C. J. Clawson, F. W. Barsalow et al., The Savings and Loan Industry in California (South Pasadena, Calif., 1960), pp. II, 2, 5.

29. Ned Eichler, The Merchant Builders (Cambridge, Mass., 1982), 52-53. 
was acquired when the level of savings deposits was abnormally high, but when growth slumped and cash was hard to obtain, these insured loans were then sold to the Federal National Mortgage Association.

The growth of savings and loan associations also helped change the distribution of time-and-demand deposits in the commercial banks. From 1945 to 1963 the demand deposits of California banks grew faster than the national average. Prior to deregulation in the 1970 s and 1980s, financial institutions could not pay interest on demand deposits, but they could do so on time deposits and savings accounts. As a result $S \& L$ time deposits increased by 3,600 percent while those of banks grew 350 percent. ${ }^{30}$

Life insurance companies also attempted to satisfy the rising demand for mortgage money in California. In 1949, national life insurance companies, holding over ninety percent of the industry's total assets, received authorization to operate in California. From 1949 to 1954 their proportion of outstanding real-estate loans in the state rose from twentynine percent to thirty-three percent. By 1951 only thirty of the 200 life insurance companies doing business in the state had made no mortgage loans. Although their importance in the overall market declined slightly after 1954, the number of companies operating increased by seventy percent in the 1950s, and their mortgage loans increased 319 percent. Thirteen percent of all real-estate loans made by life insurance companies throughout the nation were within California by the end of the decade. ${ }^{31}$

Life insurance companies and savings and loan associations competed successfully with the commercial banks because of the more liberal terms offered to borrowers. Banks in California were limited to twenty-four-year loans for no more than seventy-five percent of the property's assessed valuation. The savings and loan associations could loan eighty percent of the assessed value for up to twenty-five years, and

30. Minsky, ed., California Banking, 110, 260, 267; Gillies and Curtis, Institutional Residential Mortgage Lending, 47; Cox, "Institutional Mortgage Lending," 150.

31. Cox, "Institutional Mortgage Lending," 115-117. 
life insurance companies often extended even more lenient terms.

In contrast to the banks in California, savings and loan associations and life insurance companies also relied on funds from other states to fuel the expanding real-estate market. In the early years of the expansion, when banks dominated the market, most of their funds were derived from the time deposits of the rapidly growing local population. As the savings and loan associations gained ascendancy in the early 1950s, the time deposits of commercial banks grow more slowly, and many of their new loans were refinancing transactions associated with the resale of existing homes. Virtually none of the banks' sources of funds for real-estate loans came from customers out of state. On the other hand, the savings and loan associations came to depend increasingly on out-of-state sources. In 1960, some 18.5 percent of the funds in California savings and loan deposits came from residents in other states. Life insurance companies imported seventy-seven percent of their funds from out of the state. ${ }^{32}$

Los Angeles and its suburbs magnified the trends that characterized real-estate financing in the rest of the state. Indeed, Los Angeles often set the trend in mortgage lending. The population of Los Angeles County increased by fifty percent between 1940 and 1950, mostly through immigration of defense-industry workers and their families. The increase of ninety-eight percent in real (inflation-adjusted) income was even more dramatic. ${ }^{33}$ The Los Angeles area also had a pattern of industrial development that helped fuel the residential boom. Defense-related industries had located in several towns and cities within the Los Angeles metropolitan areanotably Long Beach, San Pedro, Fontana, Seal Beach, and Santa Ana. These areas all had large, open agricultural fields that provided suitable spots for "tracts" where fifty to a hundred or more homes could be built at the same time. Thus, tracts of homes rapidly replaced bean fields and orange groves.

The 1954 recession slowed Los Angeles's growth consid-

32. Schaff, "Savings Function and Mortgage Investment," 254; Gillies and Curtis, Institutional Residential Mortgage Lending, 99-101.

33. Minsky, "Commercial Banking," 121. 
erably, however, and shifted building activity into multipledwelling units (apartments). Multi-unit dwellings shot up much faster in Los Angeles than in Phoenix from 1954 to 1960, especially after 1955; the boom in single-family homes before that time had saturated the area with residential homes (Table 2). By 1950, fifty-six percent of all residential units in Los Angeles and its suburbs were owner-occupied, singlefamily buildings. From 1946 to 1951 single-family homes in the Los Angeles area increased fifty-five percent, about eightyfive percent of them purchased with borrowed funds. ${ }^{34}$

As in California overall, banks had been the most important source for mortgage funds for Los Angeles and the suburbs from 1946 to 1949. Thereafter, however, the emerging competition from the savings and loan industry and life insurance companies was even more dramatic there than in the rest of the state. The amount of Los Angeles real-estate lending by the savings and loan associations first surpassed that of banks in 1949 and far exceeded it by 1951; life insurance companies passed the commercial banks in 1950 (Table 3).

Table 3. Source of Residential Mortgage Loans of $\$ 20,000$ or Less in Los Angeles County (\$ millions)

\begin{tabular}{cccc}
\hline Year & Savings and Loans & Banks & Life Insurance Companies \\
\hline 1946 & 148 & 313 & 50 \\
1947 & 200 & 382 & 83 \\
1948 & 217 & 248 & 102 \\
1949 & 219 & 178 & 121 \\
1950 & 456 & 245 & 271 \\
1951 & 425 & 219 & 256 \\
\hline
\end{tabular}

Source: James Gillies and Clayton Curtis, Institutional Residential Mortgage Lending, 1946-1951: Six Significant Years of Mortgage Lending (Los Angeles, 1956), appendix, table 7 .

34. Gillies and Curtis, Institutional Residential Mortgage Lending, 10-11. In Arizona, the recession also struck the real-estate industry but the boosterism of Arizona businesses, combined with the expansion of air conditioning as a method of cooling houses and commercial buildings, offset some of the recession-related drop. This recession, however, had already convinced Robbs to diversify his mortgage-lending operations into commercial banking. 
The intense demand for housing in Los Angeles during the entire period 1945-1960 meant that mortgage lenders had considerable difficulty in attracting a sufficient volume of funds to loan out. Banks limited their fund-raising attempts to solicitations of local depositors, but savings and loan associations followed a more aggressive campaign. The payment of high interest on time deposits was an important way Los Angeles S\&Ls attracted more funds. Interest rates (called dividends) on savings deposits in Los Angeles often exceeded three percent during a period when the prevailing rate on deposits in the rest of California was 2.5 to three percent. With this incentive, Los Angeles savings and loan associations attracted 7.2 percent of their deposits from outside the metropolitan area in 1951, and they increased that figure to eighteen percent by $1959 .{ }^{35}$

Life insurance companies also brought funds into the Los Angeles area. Almost half of their funds were outside the area in 1955-1956. Overall, outside funds financed about twenty percent of Los Angeles mortgages in the 1950s, according to an estimate by John Cox. If the criterion for outside funds is the location of the principal office of the loan-granting institution, the flow of funds into the area is even more pronounced; the Cox study indicated that about half of the mortgage loans in the early 1950s came from institutions with headquarters outside the Los Angeles area, although that proportion had declined to about a third by $1960 .{ }^{36}$

All Los Angeles County financial institutions gained funds for new loans by selling the mortgages in their portfolios to the Federal National Mortgage Association. In 1951 a remarkable 23.5 percent of the $\$ 677$ million of FHA and VA mortgages that this government agency bought nationwide were linked to Los Angeles properties. ${ }^{37}$

The California real-estate boom in the late 1940s produced lasting changes in the state's financial industry. The defense-related industries attracted large inflows of people

35. Ibid., 59-60.

36. Cox, "Institutional Mortgage Lending," 92, 101. Cox's information is based on survey data that has been closed to outside researchers.

37. Gillies and Curtis, Institutional Residential Mortgage Lending, 194. 
from other states and stimulated the building industry. Local banks, dependent upon their savings deposits to finance loans on real estate, were unable to attract sufficient funds because of the low interest they paid to depositors. This weakness, combined with fears about the risks associated with the possibility of another overblown land boom, led to their decreased willingness to lend on real estate. The position of the banks in the real-estate market eroded in the 1950s when savings and loan associations and life insurance companies stepped in to assume those added risks. Savings and loan associations emerged as the dominant force in the mortgage market, and despite some deterioration thereafter, they remained in that position through the mid-1980s.

The real estate land boom of 1945 to 1960 also wrought changes in the structure of financial institutions in both Arizona and California. Whereas in Phoenix the boom had given rise to new commercial banks and fostered promotional efforts by the business and banking community to encourage further migration, in Los Angeles the population was already in place and little promotion was needed. Phoenix entrepreneurs and some bankers pursued both innovative financing and advertising plans - for example, California bankers were less creative (but Los Angeles savings and loan institutions provided the innovative financing to fuel the boom). In both locations the boom had the same impact on the major commercial banks: the existing giants lost market share to the new and more flexible financial institutions. Both Phoenix and Los Angeles witnessed inflows of capital from eastern and midwestern investors, particularly insurance companies. As a result, the eastern financial centers unwittingly sponsored the growth of the very region that, by the 1980 s, challenged the economic, demographic, and political position of the declining rustbelt. 